\title{
Phorbol-ester mediated suppression of hASH1 synthesis: multiple ways to keep the level down
}

\author{
Edgar Benko', Aline Winkelmann², Jochen C. Meier ${ }^{2}$, Pontus B. Persson ${ }^{1}$, Holger Scholz ${ }^{1}$ and Michael Fähling ${ }^{\text {* }}$ \\ Institut für Vegetative Physiologie, Charité - Universitätsmedizin Berlin, Berlin, Germany \\ RNA Editing and Hyperexcitability Disorders Helmholtz Group, Max Delbrück Center for Molecular Medicine, Berlin, Germany
}

\section{Edited by:}

Jean-Michel Rigo, Universiteit Hasselt Belgium

\section{Reviewed by:}

Jean-Michel Rigo, Universiteit Hasselt Belgium

Julian Heng, The Australian

Regenerative Medicine Institute,

Australia

\section{${ }^{*}$ Correspondence:}

Michael Fähling, Institut für Vegetative Physiologie, Charité -

Universitätsmedizin Berlin, Hessische Str. 3-4, Berlin D-10115, Germany. e-mail: michael.faehling@charite.de
Human achaete-scute homolog-1 (hASH1), encoded by the human ASCL1 gene, belongs to the family of basic helix-loop-helix transcription factors. hASH1 and its mammalian homolog Mash1 are expressed in the central and peripheral nervous system during development, and promote early neuronal differentiation. Furthermore, hASH1 is involved in the specification of neuronal subtype identities. Misexpression of the transcription factor is correlated with a variety of tumors, including lung cancer and neuroendocrine tumors. To gain insights into the molecular mechanisms of $\mathrm{hASH} 1$ regulation, we screened for conditions causing changes in $\mathrm{hASH} 1$ gene expression rate. We found that treatment of human neuroblastoma-derived Kelly cells with phorbol 12-myristate 13-acetate (PMA) resulted in a fast, strong and long-lasting suppression of hASH1 synthesis. Reporter gene assays with constructs, in which the luciferase activity was controlled either by the ASCL 1 promoter or by the hASH1 mRNA untranslated regions (UTRs), revealed a mainly UTR-dependent mechanism. The $h A S H 1$ promoter activity was decreased only after $48 \mathrm{~h}$ of PMA administration. Our data indicate that different mechanisms acting consecutively at the transcriptional and post-transcriptional level are responsible for hASH1 suppression after PMA treatment. We provide evidence that short term inhibition of hASH1 synthesis is attributed to hASH1 mRNA destabilization, which seems to depend mainly on protein kinase $\mathrm{C}$ activity. Under prolonged conditions (48 h), hASH1 suppression is mediated by decreased promoter activity and inhibition of mRNA translation.

Keywords: human achaete-scute homolog-1, Mash1, ASCL1, gene expression, post-transcriptional control

\section{INTRODUCTION}

During neuronal development the spatial and temporal fulfillment of specific gene expression programs is crucial for the formation of normal size, shape and integrity of the brain structures. This process is critically controlled by a set of basic helix-loop-helix (bHLH) transcription factors (Kageyama et al., 2005). It has been hypothesized that all neural stem cells gain neurogenic competency at a certain point, and that repressor-type bHLH factors (e.g., Hes 1; hairy and enhancer of split 1) brake the neurogenic process by repressing the activator-type bHLH genes and thereby coordinate the neuronal differentiation program (Kageyama et al., 2005). Moreover, homeodomain and zinc-finger DNA-binding proteins function in concert to modify or regulate the activity of bHLH factors (Howard, 2005). Once induced, combined activation of bHLH genes can specify different types of neurons from those induced by each bHLH transcription factor alone (Kageyama et al., 2005). Thus, the neuronal development and cell fate determination is quite complex.

Human achaete-scute homolog-1 (hASH1) belongs to the activator-type of the bHLH transcription factor family. The ASCL1 gene product is designated hASH1 for the human form and Mash1 for the mammalian homolog. The latter term is commonly used for the corresponding mRNA/protein in rodents. It has been shown that expression of the pro-neural gene ASCL1 commits cells to a neuronal fate (Guillemot et al., 1993). Thus, Mash1 plays an important role in the commitment and differentiation of neuronal and neuroendocrine cells in the central nervous system, as well as in the generation of olfactory and autonomic neurons (Howard, 2005). The function of Mash1 is closely linked to pairedlike homeobox 2a (Phox2a) and Phox 2b, two factors that regulate expression of tyrosine hydroxylase (TH) and dopamine beta hydroxylase (DBH), respectively (Zellmer et al., 1995; Yang et al., 1998; Howard, 2005).

Retrovirus-mediated expression of hASH1 caused a change in the fate of adult hippocampal stem/progenitor cells in favor of the generation of oligodendrocytic lineage cells (Jessberger et al., 2008). Furthermore, forced expression of Ascll was sufficient to induce immature, neuronal features in mouse fibroblasts. The additional expression of Brn2 (brain-specific homeobox/POU domain protein 2) and Myt1l (myelin transcription factor 1-like) converted mouse embryonic and postnatal fibroblasts into functional neurons in vitro (Vierbuchen et al., 2010).

Mash1 knock-out mice die within $24 \mathrm{~h}$ after birth (Guillemot et al., 1993). Deletion of Mash1 impaired the generation of sympathetic, parasympathetic, and enteric neurons as well as neural progenitor cells, especially in the olfactory sensory epithelium and the ventral telencephalon (Guillemot et al., 1993; Hirsch et al., 1998; Lo et al., 1998; Casarosa et al., 1999; Horton et al., 1999; Cau et al., 2002; Wildner et al., 2006). Furthermore, mutations in the ASCL1 gene are associated with the congenital central hypoventilation syndrome (CCHS) phenotype (de Pontual et al., 2003; Sasaki et al., 2003). 
Besides its crucial function in neurogenesis, misexpression of the ASCL1 gene is associated with various tumors, including lung cancer, neuroendocrine tumors, carcinoid tumors, and pancreatic adenocarcinomas, among others (Ito et al., 2001; Axelson, 2004; Ball, 2004), and cellular tumorigenicity could be modulated by Mash1 (Jiang et al., 2009). The role of ASCL1 in neuroblastomas, which reflect an early arrest of neuronal differentiation, is controversial: While it has been reported that ASCL1 is highly expressed in undifferentiated neuroblastomas (Bourdeaut et al., 2009), ASCL1 was not increased in neuroblastoma with unfavorable outcome in another investigations (Gestblom et al., 1999; Ichimiya et al., 2001).

Recently, several Mash1 target genes have been identified (Gohlke et al., 2008; Johansson et al., 2009). However, although the crucial function of Mash1/hASH1 in cell fate determination, neurogenesis, and tumorigenesis has been well documented, little is known regarding conditions, trans-factors, and mechanisms that modulate its gene expression rate. It has been shown that Mash1/hASH1 is tightly regulated by the Notch [Drosophila Notch homolog 1 (controlling the ectodermal and neural cell fate in Drosophila)] pathway. Activation of Notch receptors cause their interaction with the DNA-binding protein RBP-Jk and subsequent enhanced expression of HES-1, which, in turn, represses downstream target genes such as ASCL1 (Chen et al., 1997; Apelqvist et al., 1999; Axelson, 2004). Furthermore, Notch1 has been suggested to stimulate accelerated hASH1 protein turnover by increased proteasomal degradation (Sriuranpong et al., 2002). We recently demonstrated that ASCL1 gene expression can be further modulated by posttranscriptional mechanisms affecting the hASH1 mRNA translation rate (Fähling et al., 2009).

Regulation of gene expression rate at the post-transcriptional level is mainly attributed to the interaction of trans-factors, i.e., RNA-binding proteins (RNA-BPs) or microRNAs (miRNAs), with cis-elements, that are mainly located in the mRNA untranslated regions (UTRs; Bolognani and Perrone-Bizzozero, 2008; Martino et al., 2009). These trans-factors modulate the stability, subcellular localization and efficiency of translation of bound transcripts.

To obtain insights into the molecular mechanisms of hASH1 regulation, we searched for conditions that would change ASCL1 gene expression rates with a special effort on post-transcriptional, hASH1 mRNA UTR mediated, control. For this purpose human neuroblastoma-derived Kelly cells were used, which express hASH1 at constantly high level and may thus contain all essential factors necessary for hASH1 expression. Initial experiments revealed that phorbol 12-myristate 13-acetate (PMA) treatment of Kelly cells caused a fast, strong and long-lasting inhibition of hASH1 synthesis. Phorbol-esters are known to induce differentiation processes but also promote tumor growth, both conditions that are related to hASH1 function. The aim of this study therefore was to investigate the mechanisms how phorbol-esters may inhibit hASH1 expression.

\section{MATERIALS AND METHODS CELL CULTURE}

Human neuroblastoma-derived Kelly cells (ACC 355) were obtained from the American Type Culture Collection (ATCC) and grown at $37^{\circ} \mathrm{C}, 5 \% \mathrm{CO}_{2}$ in $60-\mathrm{mm}$ dishes in RPMI medium (PAA Laboratories, Pasching, Austria) supplemented with 10\% fetal calf serum (FCS; Biochrom KG, Berlin, Germany), $100 \mathrm{U} / \mathrm{ml}$ penicillin, $100 \mu \mathrm{g} / \mathrm{ml}$ streptomycin, and 1\% glutamate (all from Invitrogen, Karlsruhe, Germany). If not otherwise stated, Kelly cells were treated with 40 nM PMA solved in ethanol. In control experiments the cells were incubated with the solvent alone.

For the preparation of primary neurons time-pregnant rats were sacrificed according to the permit (LaGeSo, 0122/07) given by the Office for Health Protection and Technical Safety of the regional government of Berlin and in compliance with regulations laid down in the European Community Council Directive. Cortex cells from E19 Wistar rats were prepared as previously described for hippocampal neurons (Eichler et al., 2008) and maintained for 8 days in vitro in B27- and 1\% FCS-supplemented Neurobasal medium (Brewer and Cotman, 1989). The initial cell density of cortex cells from E19 Wistar rats was $68,000 / \mathrm{cm}^{2}$. On day 2 in vitro (d.i.v. 2), cells were incubated for $6 \mathrm{~h}$ with $20 \mathrm{nM}$ PMA solved in ethanol, and the control culture was treated with $0.2 \%$ of the solvent.

\section{IMMUNOFLUORESCENCE}

In cortex cell cultures from E19 Wistar rats the Mash1 protein was visualized using a monoclonal mouse antibody (MASH1, 1:500, BD Biosciences, USA). The secondary antibody (affinity purified and multi-labeling declared) coupled to tetramethylrhodamine isothiocyanate (TRITC) was purchased from Jackson ImmunoResearch Laboratories (West Grove, PA, USA). Neurons were fixed using an ice-cold mixture of $4 \%$ paraformaldehyde (PFA) and $4 \%$ sucrose in phosphate-buffered saline (PBS; $15 \mathrm{~min}$ at room temperature). After three wash steps in PBS coverslips were incubated overnight in $\mathrm{PBS} /$ gelatin at $4^{\circ} \mathrm{C}$, prior to staining with antibodies. First and secondary antibodies were incubated at room temperature for $1 \mathrm{~h}$ and $45 \mathrm{~min}$, respectively. In between antibody incubations, coverslips were washed four times, each, with PBS/gelatin. Coverslips were finally mounted on microscope slides using DAPI-containing Vectashield medium for visualization of cell nuclei (Vector Laboratories, Burlingame, CA, USA).

Labeled neurons were visualized with a standard epifluorescence microscope (Olympus BX51, Olympus Deutschland GmbH, Hamburg, Germany) under U Plan FL N 10.0× objective (Olympus). Appropriate filters (U-MSP100v2 MFISH DAPI and U-MSP102v1 MFISH Cy3; Olympus GmbH, Germany) allowed the detection and separation of fluorescent signals. Images were acquired using a 14-bit cooled CCD camera (Spot PURSUIT, Visitron Systems $\mathrm{GmbH}$, Puchheim, Germany) and the software Metamorph (Universal Imaging Corp., Downingtown, PA, USA).

\section{DETERMINATION OF mRNA AND PROTEIN LEVELS}

Total RNA was isolated from cultured cells using the RNA-Bee ${ }^{\mathrm{TM}}$ reagent (AMS Biotechnology, Germany). First-strand cDNA synthesis was performed with $2 \mu \mathrm{g}$ of total RNA using oligo(dT) primers and superscript II reverse transcriptase (Invitrogen $\mathrm{GmbH}$, Karlsruhe, Germany). Quantitative PCR analysis was performed in triplicate with the GeneAmp 5700 system (Applied Biosystems, Darmstadt, Germany) according to the manufacturer's instructions. The following intron bridging primers were used for the amplification reactions: hASH1-forward: 5'-CGACTTCACCAACTGGTTCT, hASH1-reverse: 5'-CCGTGAATGATTGGAGTGC, beta-actin-forward: 5'-TGAAGTGGTACGTGGACATC, beta-actin- 
reverse: 5'-GTCATAGTCCGCCTAGAAGC, GAPDH-forward: 5'-CACCATCTTCCAGGAGCGAG,

GAPDH-reverse:

5'-GCAGGAGGCATTGCTGAT. The expression levels of $h A S H 1$ mRNA were normalized to beta-actin or GAPDH using the $\Delta C_{t}$ method. Parallelism of standard curves of the test and control was confirmed.

Cellular protein extracts were prepared from cultured cells as described previously (Kirschner et al., 2006) and separated on a $10 \%$ polyacrylamide gel. The proteins were transferred onto polyvinylidene difluoride membranes (Amersham Pharmacia Biotech, Freiburg, Germany) using a Bio-Rad Mini Trans-Blot transfer cell (Bio-Rad, Munich, Germany). Immunodetection of hASH1 was performed according to our routine protocol (Fähling et al., 2006a,b) using a 1:500 dilution of the anti-Mash1 primary antibody (\#556604, BD Biosciences, Heidelberg, Germany). As a loading control detection of beta-actin (\#MAB1501R, Chemicon, Schwalbach, Germany; dilution 1:1.000) and GAPDH (\#BM439, Acris Antibodies GmbH, Hiddenhausen, Germany; dilution: 1:1.500) was performed. The reference antibodies were applied after stripping of the membranes with bi-distilled water for $5 \mathrm{~min}, 0.2 \mathrm{M} \mathrm{NaOH}$ for up to $5 \mathrm{~min}$ and a final wash with bi-distilled water for $5 \mathrm{~min}$. Primary antibodies were detected with peroxidase-coupled secondary antibodies, and the reaction products were visualized with the enhanced chemiluminescence system (Amersham Pharmacia Biotech, Freiburg, Germany). Autoradiographic signals were scanned and quantified using the Scion Image software (Scion Corporation).

Quantification of Mash1 fluorescence (signal) was achieved using intensity measurements within circular regions of interest (diameter $5 \mu \mathrm{m}$ ) projected on the center of nuclei. Background fluorescence (noise) was quantified likewise, except that cell-free regions of interest were chosen. For convenience, the original intensity values (ranging from 0 to 255 , with " 0 " representing white perception and " 255 " black color) were subtracted from the value of 255 so that increasing intensity values indicate increasing fluorescence intensities. Statistical analysis (unpaired Student's $t$-test) was performed using the software Origin (MicroCal, Northampton, MA, USA).

\section{PLASMIDS}

A 1436-bp fragment of the predicted ASCL1 gene promoter sequence (NCBI number U77616) was cloned by PCR and ligated into the pGL3basic reporter vector (Promega GmbH, Mannheim, Germany). Likewise, we also obtained a 1132-bp fragment carrying the murine Ascl1 promoter (Ensembl gene ENSMUSG00000020052).

For the generation of luciferase reporter constructs that express the firefly-luciferase in a $h A S H 1$ mRNA UTRs dependent manner, the pGL3promotor vector (Promega $\mathrm{GmbH}$, Mannheim, Germany), which contains a constitutive SV40 promoter, was modified by replacement of the vector specific $5^{\prime}$ - and 3'UTRs of luciferase mRNA by the human $h A S H 1$ mRNA UTRs as described in Fähling et al. (2009). The quality of processed vectors was confirmed by sequencing.

\section{CELL TRANSFECTION AND REPORTER GENE ASSAYS}

Transient transfections of Kelly cells were performed as described previously (Fähling et al., 2009). Briefly: cultured cells were grown to approximately $70 \%$ confluence in 96 -well plates ( $\mu$ Clear Platte 96K,
Greiner BIO-ONE GmbH, Frickenhausen, Germany) and transiently co-transfected with a reporter construct containing the firefly-luciferase gene flanked by the $5^{\prime}$ - and/or 3'UTRs of $h A S H 1$ mRNA and the renilla luciferase phRL-TK vector (Promega, Mannheim, Germany) using the Roti ${ }^{\circledast}$ Fect Transfection Reagent (Carl Roth GmbH \& Co. $\mathrm{KG}$, Karlsruhe, Germany) according to the manufacturer's protocol. Activity levels of renilla luciferase served for normalization of transfection efficiencies. The luciferase activities were measured in a luminometer (Labsystems Luminoskan RS, Helsinki, Finland).

\section{DETERMINATION OF mRNA AND PROTEIN HALF LIFE TIMES}

For the estimation of $h A S H 1$ mRNA and protein stabilities, human neuroblastoma-derived Kelly cells were cultured as described above and treated with PMA or solvent (control). Following PMA administration, cell culture media were supplemented with actinomycin D $(5 \mu \mathrm{g} / \mathrm{ml})$, an inhibitor of mRNA transcription to estimate mRNA half life, or cycloheximide $(20 \mu \mathrm{g} / \mathrm{ml})$, which blocks mRNA translation, for determination of hASH1 protein half life times. Incubation of the cells was continued for different time periods as indicated. RNA and protein lysates were prepared and quantified as described before. Decreasing mRNA and protein levels represent the rate of decay under the conditions tested.

\section{PROTEIN KINASE INHIBITION}

To assess the influence of the protein kinase C (PKC), cells were pre-incubated with either staurosporine (40 nM; \#S4400, SIGMAALDRICH, Germany), or GF109203X (5 $\mu \mathrm{M}$; \#B6292, SIGMAALDRICH, Germany) according to the manufacturer's instructions for $4 \mathrm{~h}$ prior to the treatment with PMA or solvent (control). Furthermore, KT-5720 (2 $\mu$ M; \#BML-EI-199, Enzo Life Sciences GmbH, Germany) was used for inhibition of protein kinase A (PKA).

\section{STATISTICS}

If not otherwise indicated, all values are presented as means $\pm \mathrm{SD}$. Student's paired $t$-test was performed to reveal statistical significances. $p$ Values less than 0.05 were considered significant.

\section{RESULTS PHORBOL 12-MYRISTATE 13-ACETATE SUPPRESSES hASH1 SYNTHESIS}

Administration of PMA (40 nM) caused a fast and long-lasting suppression of hASH1 synthesis in Kelly cells. At the mRNA level this inhibitory effect was evident after $3 \mathrm{~h}$, during which the $h A S H 1$ mRNA content dropped to $44 \%$ compared to control conditions (Figure 1). This down-regulation of $h A S H 1$ transcripts was relatively stable for up to $24 \mathrm{~h}$. Following $48 \mathrm{~h}$ of PMA treatment, the hASH1 mRNA level was still moderately reduced (57\% compared to control). The initial $24 \mathrm{~h}$ of incubation with PMA caused a decrease of both $h A S H 1$ mRNA as well as protein levels. However, at $48 \mathrm{~h}$ of PMA treatment the hASH1 protein level further dropped (to $18 \%$ compared to control), whereas $h A S H 1$ transcripts tended to recover from suppression (Figure 1).

\section{REGULATORY ELEMENTS MEDIATING PMA INDUCED hASH1 SUPPRESSION}

Gene expression rates are controlled at the transcriptional and posttranscriptional level by interaction of trans-factors with cis-regulatory elements. Post-transcriptional regulation involves changes 
in mRNA stability, mRNA translation rate or mRNA localization, which is attributed to RNA-BPs or miRNAs interacting mainly with the mRNA UTRs (Kuersten and Goodwin, 2003). Reporter gene assays were applied to search for potential regulatory elements in the ASCL1 promoter and in the mRNA UTRs. No significant changes in ASCL1 promoter activity following PMA treatment for

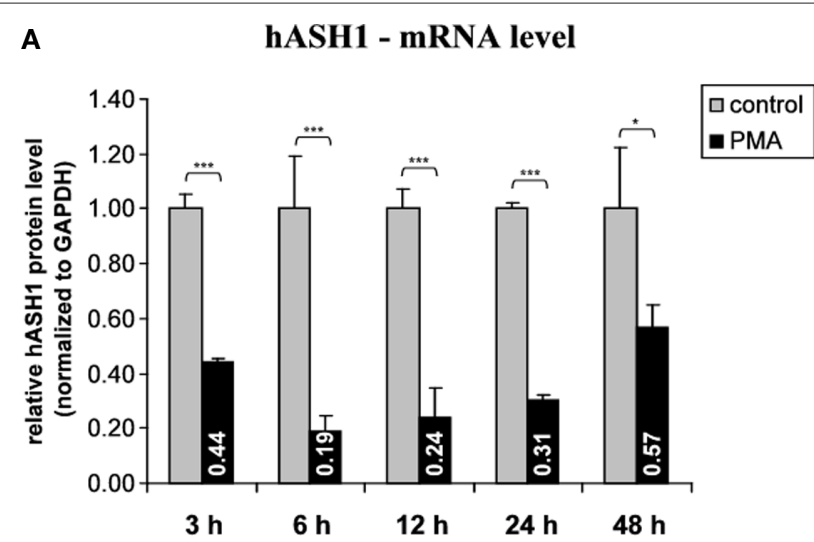

B

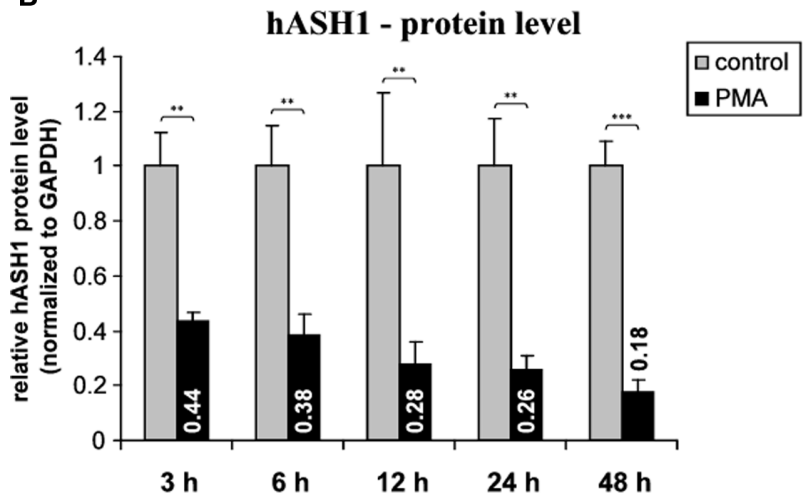

C

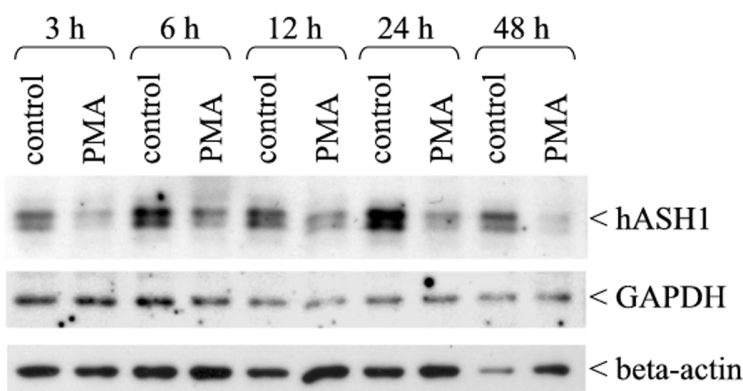

FIGURE 1 | Human achaete-scute homolog-1 mRNA and protein levels following PMA (40 nM) treatment. (A) Determination of $h A S H 1$ mRNA levels by qRT-PCR $(n=9)$. (B) Statistical analysis of hASH1 protein levels obtained by Western Blotting ( $n=6)$. (C) Representative Western blot analysis. Pools of six independent samples per condition are shown. Control cells were treated with PMA solvent (ethanol). Detection of GAPDH and beta-actin served as loading controls. Shown are mean values, and error bars represent the standard deviation (SD). ${ }^{*} p<0.05,{ }^{* *} p<0.01,{ }^{* * *} p<0.001$.
$24 \mathrm{~h}$ were observed in transfected Kelly cells. Only prolonged ( $48 \mathrm{~h}$ ) PMA treatment reduced the luciferase activity, indicating a delayed inhibitory effect of PMA on the ASCL1 promoter (Figure 2A).

In contrast, $h A S H 1$ mRNA UTR-dependent reporter gene assays indicated a post-transcriptional inhibition which started approximately at $6 \mathrm{~h}$ and became significant after $12 \mathrm{~h}$ of PMA treatment (Figure 2B). The suppressing influence reached similar levels (down to approximately $30 \%$ compared to control) as found at the native $h A S H 1$ mRNA and protein levels. Interestingly, the $h A S H 1$ mRNA UTR mediated suppression of protein synthesis was constant up to $48 \mathrm{~h}$.

Responsible regulatory elements may be located either in the hASH1 mRNA 5'- or 3'UTR. Therefore, we separately tested the influence of the $h A S H 1$ mRNA $5^{\prime} \mathrm{UTR}$ and $3^{\prime} \mathrm{UTR}$. It turned out that both, the $5^{\prime}$ - as well as the $3^{\prime}$ UTR have independent inhibitory properties (Figure 3). The combination of $5^{\prime}$ - and 3'UTR, however,

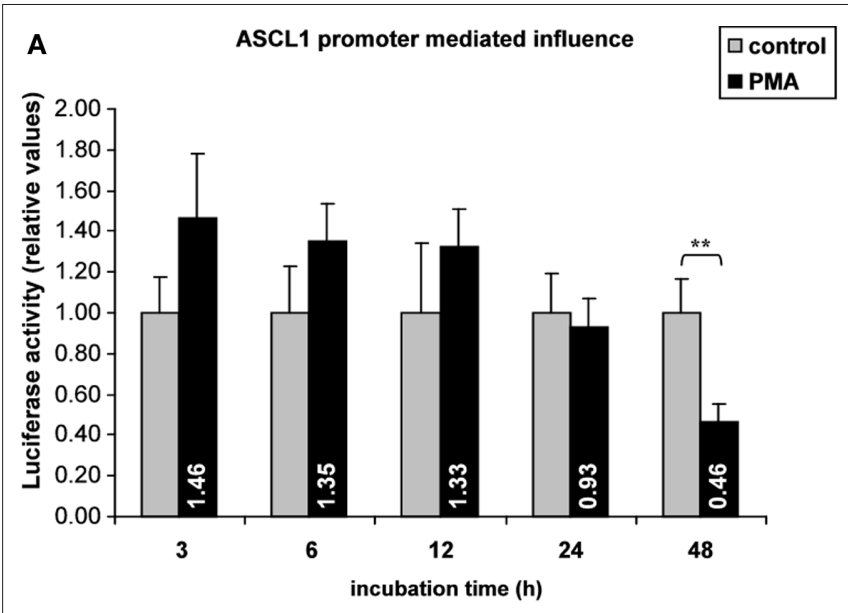

B
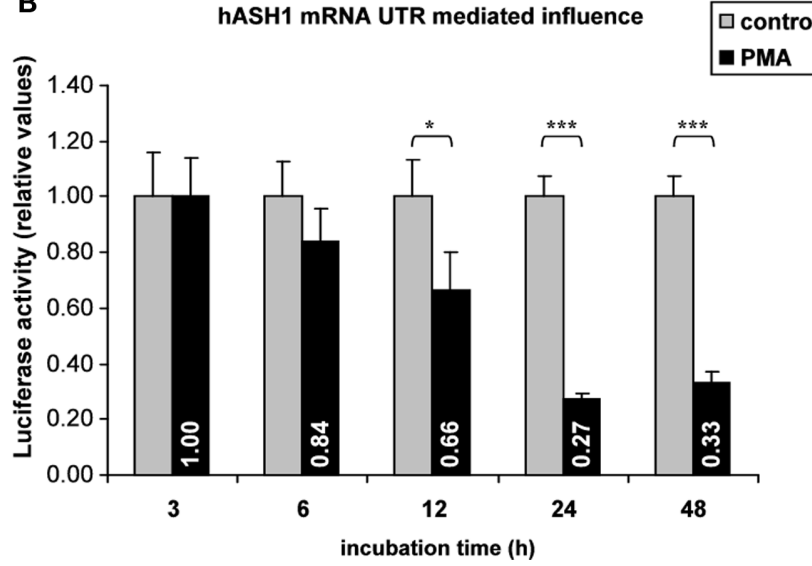

FIGURE 2 | Reporter gene assays. Kelly cells were transiently transfected (36 h) with reporter gene vectors containing either the ASCL 1 promoter sequence or the $h A S H 1$ mRNA 5 '- and $3^{\prime}$ UTRs followed by PMA administration (40 nM). In hASH1 mRNA UTR-dependent reporter assays the firefly-luciferase transcription rate was controlled by the constitutive SV40 promoter. Values of firefly-luciferase activity were normalized to the co-transfected renilla-luciferase. (A) Influence of ASCL1 promoter on PMA-mediated reporter gene activity. (B) hASH1 mRNA 5'- and 3'UTRdependent response on gene expression rate following PMA treatment. $n=12 ;{ }^{*} p<0.05,{ }^{*} p<0.01,{ }^{* *} p<0.001$. 
caused the strongest suppressing effect which seems to be additive. This observation suggests that trans-factors interacting at the $5^{\prime}$ or 3'UTR are necessary for the full inhibitory effect of PMA.

We then determined the optimal PMA dose for the suppressing influence of $h A S H 1$ mRNA 5'-/3'UTR combination. Four nanomolars PMA (24 h) was already sufficient to suppress the reporter gene activity significantly, and $40 \mathrm{nM}$ PMA exerted the strongest effects (Figure A1 in Appendix).

The specificity of hASH1 mRNA UTR-dependent reporter gene assays was demonstrated by the comparison of different substances. A set of results is shown in Figure 4. We found that,

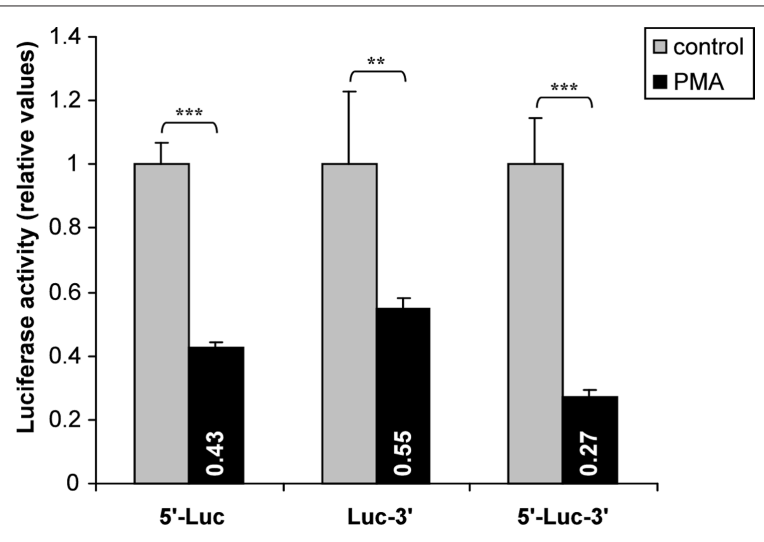

FIGURE 3 | Influence of hASH1 mRNA 5' - and 3'UTRs in PMA-mediated post-transcriptional control. Kelly cells were transiently transfected with reporter constructs where the $5^{\prime}$ - or $3^{\prime} U T R$ of firefly-luciferase mRNA were separately replaced by the hASH1 5'- (5'-Luc) or 3'UTR (Luc-3'). The firefly-luciferase mRNA flanked by both, the hASH1 mRNA 5'- and 3'UTR $\left(5^{\prime}\right.$-Luc- $\left.3^{\prime}\right)$ showed the strongest suppressing influence in response to PMA treatment $(40 \mathrm{nM}) . n=12 ;{ }^{* *} p<0.01,{ }^{* * *} p<0.001$.

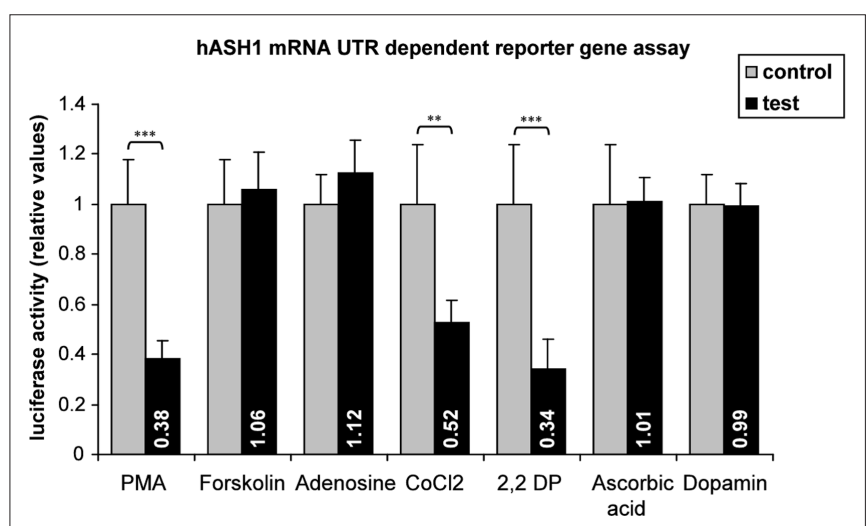

FIGURE 4 | Screening for conditions leading to an alteration in gene expression rate mediated by hASH1 mRNA 5'- and 3'UTRs. Kelly cells were transiently transfected ( $36 \mathrm{~h}$ ) with reporter constructs where the luciferase mRNA UTRs were replaced by the hASH1 mRNA UTRs.

Transcription rate was controlled by the constitutive SV40 promoter. Cells were treated with different compounds for $24 \mathrm{~h}$. The concentrations used were: $\mathrm{PMA}=40 \mathrm{nM}$; Forskolin $=100 \mathrm{nM}$; adenosine $=100 \mathrm{nM}$; cobaltous chloride $\left(\mathrm{CoCl}_{2}\right)=50 \mathrm{nM}$; 2,2'-Dipyridyl (2,2 DP) $=100 \mathrm{mM}$; ascorbic acid $=100 \mathrm{mM}$; dopamine $=100 \mathrm{nM}$. Data are relative to the relevant control conditions $\left(\mathrm{H}_{2} \mathrm{O}\right.$, ethanol, DMSO respectively). $n=12 ;{ }^{*} p<0.01$, *** $p<0.001$. for instance, PMA suppressed hASH1 mRNA UTR-dependent reporter gene assays, whereas Forskolin an activator of the adenylyl cyclase/PKA signaling pathway (Insel and Ostrom, 2003), did not. Furthermore, substances commonly used to induce a chemical hypoxia such as cobaltous chloride [competes with iron $\left(\mathrm{Fe}^{2+}\right)$ ] or 2,2'-Dipyridyl (which chelates $\mathrm{Fe}^{2+}$ ) significantly suppressed the reporter gene activity.

\section{MECHANISMS INVOLVED IN hASH1 INHIBITION}

From the mechanistic point of view the data gathered so far indicate that $h A S H 1$ mRNA UTR mediated control may cause an alteration in hASH1 mRNA stability at early time points (up to $24 \mathrm{~h}$ ). This is supported by mRNA stability assays (Figure 5A). After treatment with actinomycin D which blocks mRNA transcription, the mRNA degradation rate was significantly higher in PMA-treated cells $(6 \mathrm{~h})$ compared to control cells $(1.02 \pm 0.04 \mathrm{~h}$ for control and $0.46 \pm 0.03 \mathrm{~h}$ for PMA-treated cells). At $48 \mathrm{~h}$, however, the hASH1 mRNA half life was similar under both conditions $(1.07 \pm 0.06 \mathrm{~h}$ for control and $1.18 \pm 0.09 \mathrm{~h}$ for PMA treatment; Figure 5B). Thus, the reduced $h A S H 1 \mathrm{mRNA}$ level during prolonged PMA treatment seems to be determined by inhibition of mRNA transcription, as indicated by ASCL1 promoter assays (Figure 2B).

Following $48 \mathrm{~h}$ of PMA treatment, the hASH1 protein level further dropped (from $30 \%$ at $24 \mathrm{~h}$ to $11 \%$ at $48 \mathrm{~h}$; Figure 1B), which is in contrast to the partial recovery of $h A S H 1$ mRNA from PMAdependent inhibition after $48 \mathrm{~h}$ (Figure 1A). The latter observation could be explained either by alteration in the hASH1 protein half life or inhibition of $h A S H 1$ mRNA translation rate.

We therefore determined the hASH1 protein half life under prolonged conditions $(48 \mathrm{~h})$. It turned out that protein turnover was similar under control condition and following PMA treatment $(1.12 \pm 0.13 \mathrm{~h}$ for control and $1.2 \pm 0.2 \mathrm{~h}$ for PMA treatment; Figures 5C,D). Considering that $h A S H 1$ mRNA UTR-dependent reporter gene assays showed an inhibition under prolonged conditions, which cannot be attributed to an alteration in mRNA stability (Figure 5B), these data implicate that $h A S H 1$ mRNA translation is inhibited by PMA treatment at $48 \mathrm{~h}$ PMA.

Taken together, these data suggest that reduced $h A S H 1$ mRNA levels up to $24 \mathrm{~h}$ of PMA treatment result from reduced mRNA stability. At $48 \mathrm{~h}$ of PMA decreased ASCL1 promoter activity reflects inhibition of gene transcription. Furthermore, under prolonged conditions suppressed hASH1 protein levels seem to be also attributed to reduced $h A S H 1$ mRNA translation.

Both, hASH1 mRNA and -protein half lifes are very short (approximately $1 \mathrm{~h}$ each), indicating a high turnover rate, which is about one-third only of that determined for the firefly-luciferase (as reported by Promega Inc.). This might explain the delay in the PMA-mediated response observed by hASH1 mRNA UTRdependent reporter gene assays compared to native hASH1 mRNA and protein levels (see Figures 1 and 2).

\section{ROLE OF PROTEIN KINASE C IN THE CONTROL OF hASH1 SYNTHESIS}

Phorbol 12-myristate 13-acetate is a known activator of the PKC (Liu and Heckman, 1998). We therefore asked whether transcriptional and/or post-transcriptional responses in the alteration of hASH1 synthesis mediated by PMA are attributed to the action of PKC. 


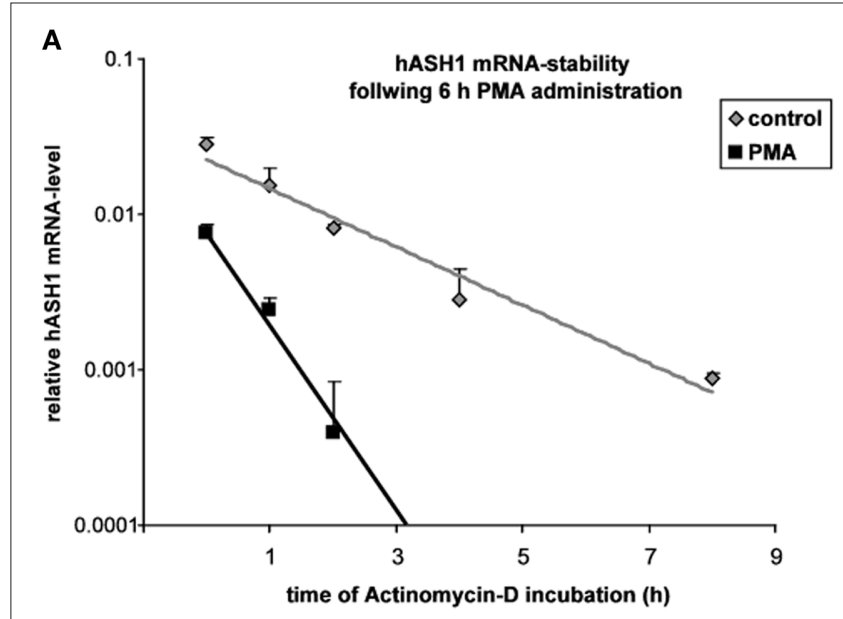

C

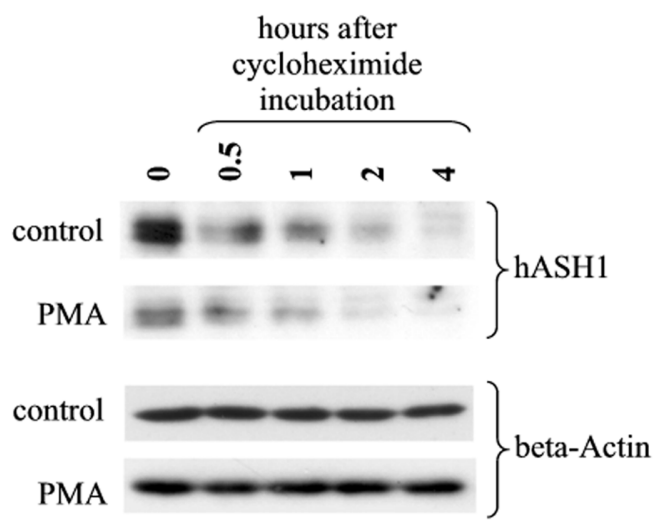

FIGURE 5 | Estimation of hASH1 mRNA and protein half life. Kelly cells were incubated for 6 or $48 \mathrm{~h}$ under control conditions or were treated with PMA (40 nM). Following solvent/PMA pre-incubation cell culture media were supplemented with either actinomycin D to assess $h A S H 1$ mRNA half life or cycloheximide for the estimation of $h A S H 1$ protein stability. (A) $h A S H 1$ mRNA stability at $6 \mathrm{~h}$ control vs.

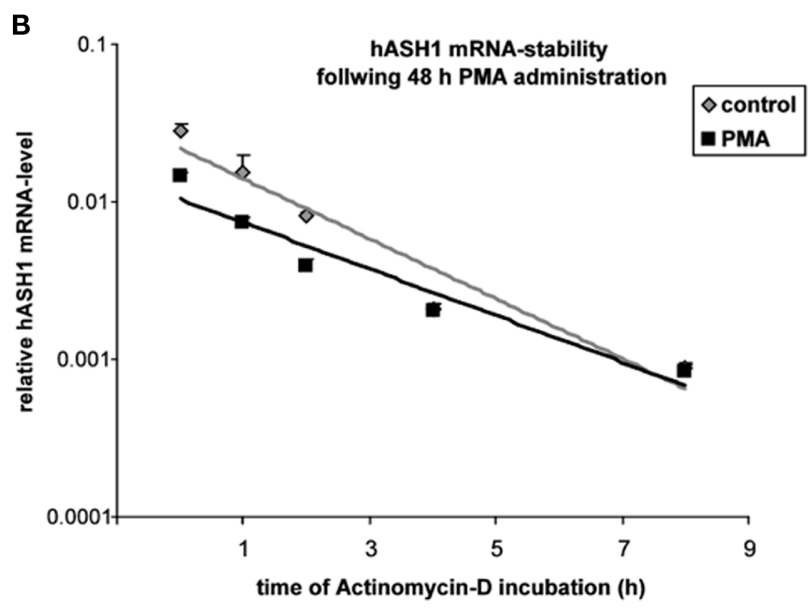

D

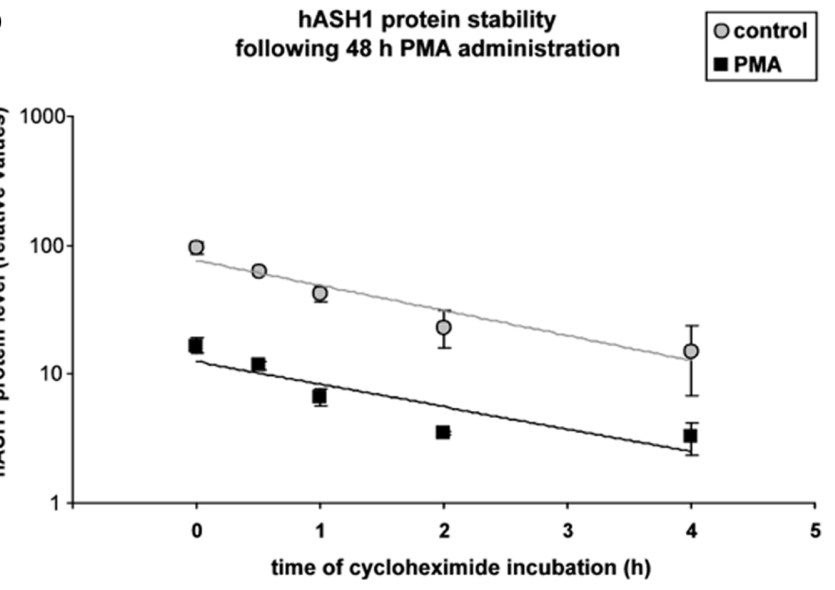

PMA. $m R N A$ half lifes are: control $=1.02 \pm 0.04 \mathrm{~h} ; \mathrm{PMA}=0.46 \pm 0.03 \mathrm{~h}$. (B) $h A S H 1$ mRNA stability at $48 \mathrm{~h}$ control vs. PMA. mRNA half lifes are: control $=1.07 \pm 0.06 \mathrm{~h}$; $P M A=1.18 \pm 0.09$ h. (C) Western blot analysis. A representative data set is shown. (D) Statistical evaluation of hASH1 protein stability at $48 \mathrm{~h}$ control vs. PMA. Protein half lifes are: control $=1.12 \pm 0.13 \mathrm{~h} ; \mathrm{PMA}=1.2 \pm 0.2 \mathrm{~h} . n=3$.
To assess the impact of PKC, Kelly cells were pre-incubated with the PKC inhibitors GF109203X or staurosporine for $4 \mathrm{~h}$ prior to PMA administration. Both inhibitors diminished the PMAmediated suppression of hASH1 expression (Figure 6). However, neither GF109203X nor staurosporine completely abolished the PMA effect, indicating that, in addition to PKC, other factors also participate in hASH1 regulation following PMA administration. In this context it is important to note that GF109203X and staurosporine differently affect $h A S H 1$ mRNA level in the absence of PMA (Figure A2 in Appendix).

The influence of PKC inhibition was confirmed in $h A S H 1$ mRNA UTR-dependent reporter gene assays (Figure 7), suggesting that PKC modulates trans-factors acting at the post-transcriptional level of hASH1 synthesis. In contrast, inhibition of PKA did not influence PMA-mediated suppression of hASH1 mRNA UTR-dependent reporter gene activity. Interestingly, while staurosporine diminished the PMA-mediated suppression only moderately, treatment of GF109203X abolished the effect of PMA to a non-significant level.

\section{PMA DOWN-REGULATES MASH1 IN PRIMARY CORTICAL NEURONS}

To establish a broader cellular context for PMA regulation of hASH1 we investigated whether PMA suppresses Mash1 (the rodent homolog) protein levels also in primary cortical neurons. For this purpose we visualized Mash1 in cortical neurons isolated from E19 Wistar rats and found that PMA decreased the Mash1 level significantly according to immunofluorescence (Figure 8) and Western blot analysis (Figure A3 in Appendix). At 2 days in vitro, Mash 1 was expressed in cortical cells (Figure 8A), and PMA indeed reduced Mash1 protein (Figure 8B). In control condition, Mash1 expression exhibited cellular heterogeneity, which was not observed upon PMA treatment (Figure 8C; standard deviation, SD).

\section{DISCUSSION}

The bHLH transcription factor hASH1 plays an important role in the control of neuronal development and differentiation (Bertrand et al., 2002; Ross et al., 2003; Howard, 2005) and seems also be involved in certain types of cancer (Osada et al., 2008; Jiang et al., 2009). 


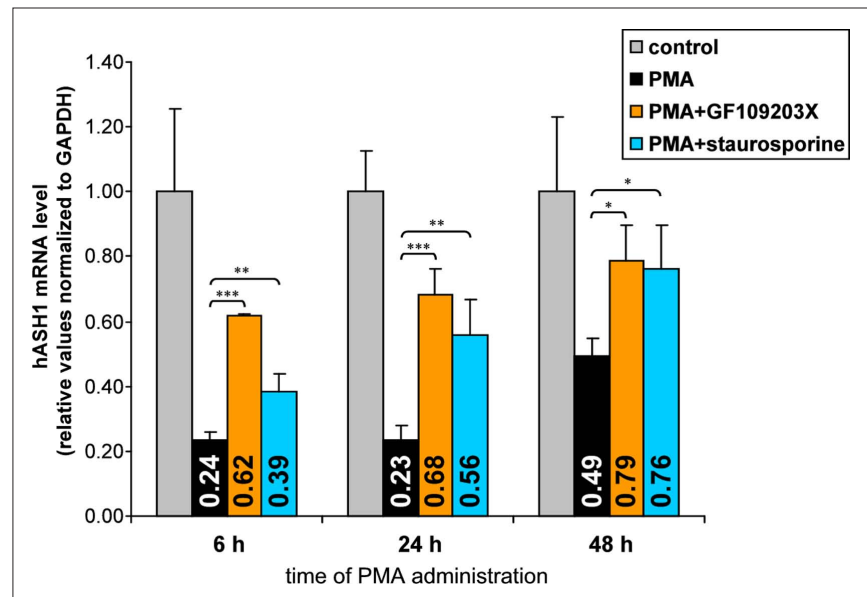

FIGURE 6 | Influence of PKC inhibition on PMA-mediated hASH1 suppression. Kelly cells were pre-incubated for $4 \mathrm{~h}$ with the PKC inhibitors GF109203X or staurosporine to block PKC activity. Then, PMA was supplemented and cells were harvested after 6,24 , and $48 \mathrm{~h}$ of PMA administration. $h A S H 1$ mRNA levels were estimated by qPCR and normalized to the influence of inhibitors alone (see Figure $\mathbf{A} 2$ in Appendix for time kinetic of PKC inhibitors). $n=9$; ${ }^{*} p<0.05,{ }^{* *} p<0.01,{ }^{* *} p<0.001$.

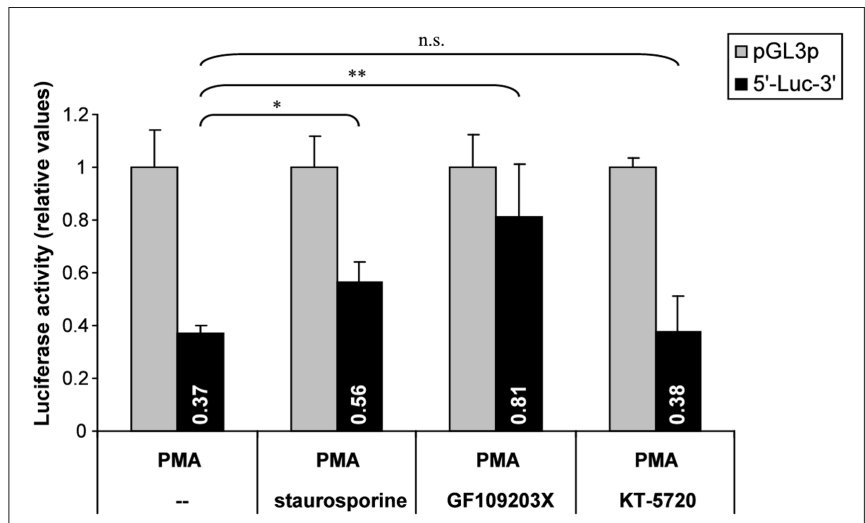

FIGURE 7 | Influence of PKC inhibition on PMA-mediated post-transcriptional control of hASH1 mRNA. Kelly cells were transfected with a reporter vector containing the hASH1 mRNA 5'- and $3^{\prime} \mathrm{UTR}$ ' as regulatory elements that determine the reporter gene expression rate. Following $24 \mathrm{~h}$ of transfection, cells were pre-incubated either with solvent (-), the PKC inhibitors staurosporine or GF109203X, or with the PKA inhibitor KT-5720 for $4 \mathrm{~h}$ and subsequent administration of PMA (24h). $n=6$; * $p<0.05$, ${ }^{* *} p<0.01$; ns, not significant.

We describe here that hASH1 undergoes a rapid suppression at the mRNA as well as protein level by administration of PMA in human neuroblastoma-derived Kelly cells and in rat primary cortex cells, indicating that this mechanism is not specific to a particular cell type. Phorbol-esters such as PMA represent surrogates of the second messenger 1,2-diacylglycerol (DAG) and are less rapidly degraded, which makes them the preferred activators of PKC used in cell culture as well as in in vivo models (Blumberg, 1991). Phorbol-esters have been implicated in stimulating several cellular responses like cell growth, differentiation, or apoptosis. In this study, we extend our current knowledge regarding the molecular mechanisms involved in down-regulation of hASH1 by PMA.
We observed a fast and strong decrease of the amount of $h A S H 1$ mRNA shortly after PMA administration, as determined by realtime PCR quantification. These findings are consistent with data reported previously (Soderholm et al., 1999; Grynfeld et al., 2000). The fast decrease in $h A S H 1$ mRNA concentration is followed by a slight attenuation at longer incubation times ( $48 \mathrm{~h})$. In contrast, the hASH1 protein level continuously declines over the monitored time span. By applying reporter gene assays which contain either the hASH1 mRNA UTRs or the ASCL1 promoter, we have shown that the rapid down-regulation of hASH1 expression rate is attributed to post-transcriptional control. Subsequently performed mRNA stability assays revealed that the UTR mediated response is a result of $h A S H 1$ mRNA destabilization. The half life of certain transcripts is mainly determined by the size of the poly-A tail. Nevertheless, endonucleolytic transcript cleavage-sites, such as AU-rich elements (ARE), represent crucial regulatory elements (Ross, 1995; Guhaniyogi and Brewer, 2001). Although mRNA stability is mainly controlled by the mRNA $3^{\prime} \mathrm{UTR}$, we found that both, the hASH1 mRNA 5'- as well as $3^{\prime}$ UTR have independent suppressing influences, indicating that multiple trans-factors are involved. Interestingly, mRNA destabilization was also found to be responsible for down-regulation of the bHLH transcription factor $\mathrm{c}-\mathrm{myc}$ under conditions of PMA administration in the human leukemia cell line K562 (Brewer, 2000). Similarly to our data, the mechanism seems to use an alternate pathway as deadenylation.

A transcriptional suppression of hASH1 synthesis in neuroblastoma cells by phorbol-ester has been linked to activation of the Notch cascade and subsequent induction of HES1, a potent repressor of ASCL1 transcription (Axelson, 2004). Interestingly, the down-regulation of $h A S H 1$ mRNA level by activated Notch 1 can be more profound than that by HES1 itself (Sriuranpong et al., 2002). These data indicate that decreased $h A S H 1$ mRNA in phorbol-ester induced cellular differentiation is a result of inhibited mRNA stabilization and mRNA transcription as well. Our findings indicate that $h A S H 1$ mRNA degradation accounts for the fast response, but is abolished under prolonged conditions when the down-regulation is mainly due to suppression of the ASCL1 promoter.

We show that under prolonged conditions of PMA administration the hASH1 protein level further declines (down to $18 \%$ compared to control) although the suppression of hASH1 mRNA level was less pronounced ( $57 \%$ compared to control), which indicates further mechanisms of gene expression control to be involved. UTR-dependent reporter gene assays support the view that, albeit the $h A S H 1$ mRNA destabilization is already abolished, the $h A S H 1$ mRNA UTRs mediate a suppressing influence. Post-transcriptional control of gene expression can be further attributed to an alteration of the efficiency of mRNA translation. Thus, the difference between hASH 1 mRNA and protein levels under prolonged condition may be explained by inhibition of $h A S H 1$ mRNA translation. However, activation of Notch signaling has also been attributed to accelerated hASH1 protein turnover (Sriuranpong et al., 2002). As the estimation of mRNA and protein levels represent the net effect of all mechanisms activated in gene expression control of a certain gene, the data gathered so far suggest that the fast, strong and long-lasting suppression of hASH1 synthesis following PMA administration is attributed to a couple of trans-factors which act synergistically and, at least in part, independently by multiple mechanisms. 

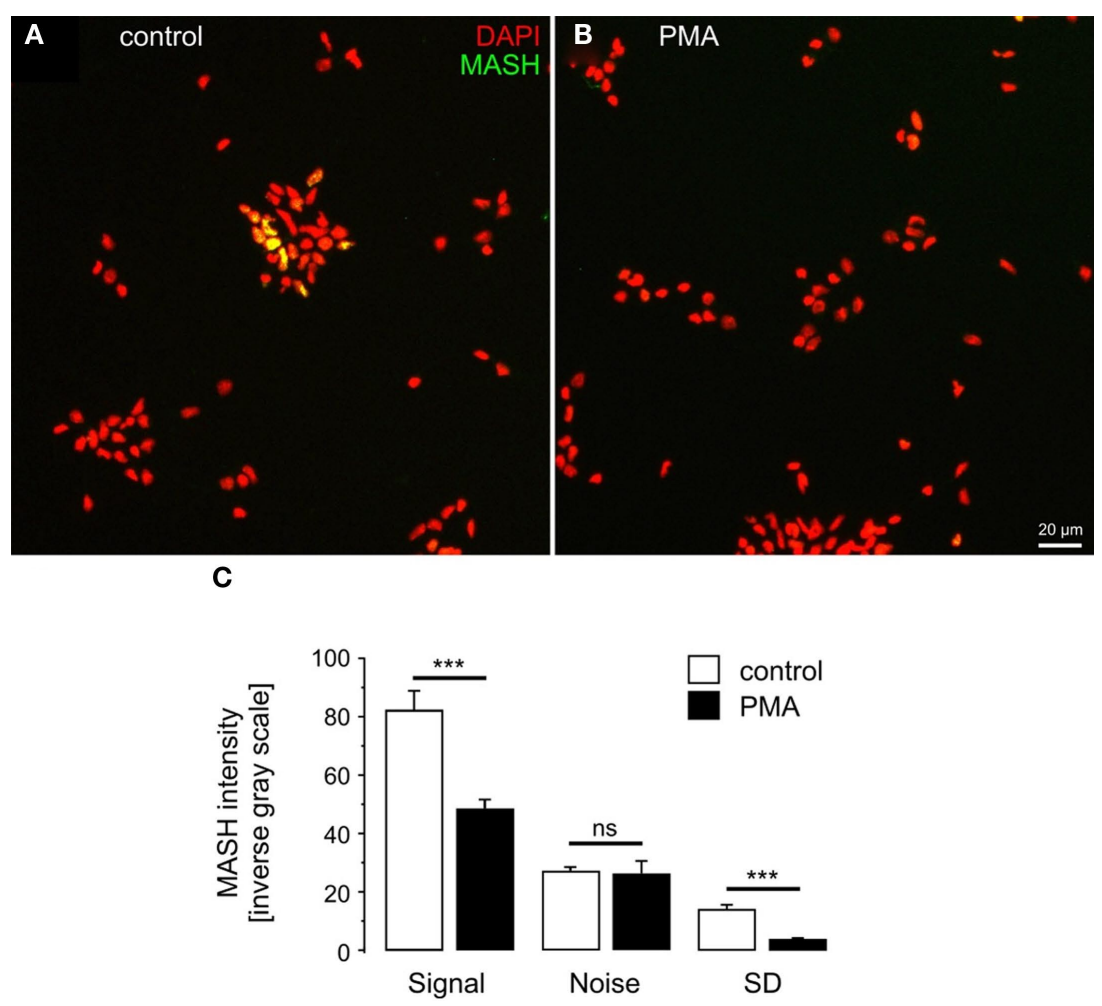

FIGURE 8 | Phorbol 12-myristate 13-acetate induces Mash1 suppression in primary cortical cells. MASH1 expression in d.i.v. 2 control (A) and PMA-treated (B) cortex cells is shown. (C) Quantitative analysis of Mash1 intensity. Note that increasing values represent increasing fluorescence intensities. The standard deviation (SD) was used as a measure of cellular heterogeneity of Mash1 expression. $n=6$ cultures; ${ }^{*} *{ }^{*} p<0.001$; ns, not significant.

To get more insights into the molecular pathways, we tested whether phorbol-ester induced hASH1 suppression is mediated by the activation of the PKC. PKCs represent the most prominent targets of phorbol-esters (Liu and Heckman, 1998). The PKC family of serine/threonine kinases comprises at least 10 different PKC isozymes which can be divided into three different groups based on their structural and biochemical properties. Noteworthy, only two of these groups, the so called classical PKCs (cPKCs, additionally activated by $\mathrm{Ca}^{2+}$ ) and the novel PKCs (nPKCs, not depending on $\mathrm{Ca}^{2+}$ ), are activated by phorbol-esters. Furthermore, the expressed PKC isozyme pattern varies depending on the cell type and tissue respectively (Mellor and Parker, 1998; Newton, 2001).

In an attempt to show whether phorbol-ester inducible PKCs are involved in the PMA-mediated hASH1 suppression we preincubated the cells for $4 \mathrm{~h}$ with staurosporine or GF109203X, both known inhibitors of PKC, prior to PMA treatment (Toullec et al., 1991). Both inhibitors diminished but did not fully prevent the suppressing PMA effect. This suggests that PKC-independent effects participate in the PMA-mediated inhibition of hASH1 synthesis. Other phorbol-ester targets, which might be involved in the activation of further signaling pathways, are at least five types of receptors that do not belong to the PKC family but also bear the DAG/ phorbol-ester binding domain $\mathrm{C} 1$. These proteins were shown to participate in signaling pathways that control cell proliferation, cell death, malignant transformation, and the metastatic cascade (Brose and Rosenmund, 2002; Yang and Kazanietz, 2003).
Interestingly, GF109203X treatment abolished the hASH1 mRNA UTR mediated influence, suggesting PKC dependency, whereas staurosporine had a much weaker though significant effect. This discrepancy may be explained by the selectivity of both compounds. It has been demonstrated that staurosporine inhibits other protein kinases in addition to PKC, thus behaves as a non-selective inhibitor (Toullec et al., 1991). This is supported by our observation that GF109203X and staurosporine differently affected $h A S H 1$ mRNA level under control conditions (Appendix). We found that treatment of Kelly cells with GF109203X caused a weak increase in $h A S H 1$ mRNA level after $4 \mathrm{~h}$. In contrast, staurosporine treatment resulted in a fast drop in $h A S H 1$ mRNA level, which was stable up to $48 \mathrm{~h}$. These data suggest that other, PKCindependent, trans-factors modulate hASH1 expression under control conditions. Consistently, one study reported that staurosporine itself can induce differentiation of the neuroblastoma cell line NB-1 (Morioka et al., 1985). Moreover, staurosporinemediated, PKC-independent, effects might even influence or dominate the response of $h A S H 1$ mRNA UTRs dependent regulation following PMA administration. Nevertheless, our findings indicate that especially the post-transcriptional control of hASH1 synthesis is PKC dependent. The inhibitory effect of GF109203X is achieved through the prevention of ATP binding to PKC and not by binding to the phorbol-ester/DAG binding site (Tamaoki et al., 1986). Therefore, these results might also be of interest under conditions of energy depletion. In line with the latter hypothesis 
we observed that iron depletion (by cobaltous chloride or 2,2'Dipyridyl), which leads to ATP deficiency, caused suppression of reporter gene activity mediated by the hASH1 mRNA UTRs. Furthermore, it has been reported that hASH1 synthesis is suppressed in hypoxia (Jogi et al., 2002; McGovern et al., 2010). Thus, it can be hypothesized that post-transcriptional control of hASH1 synthesis involves ATP dependent mechanisms, which may be attributed to modulation of PKC activation.

Taken together, we provide evidence that the PMA induced down-regulation of hASH1 synthesis involves PKC dependent as well as independent signaling pathways. The changes of hASH1 expression in response to PMA are complex and involve post-transcriptional control mechanisms. Especially the fast and

\section{REFERENCES}

Apelqvist, A., Li, H., Sommer, L., Beatus, P., Anderson, D. J., Honjo, T., Hrabe de Angelis, M., Lendahl, U., and Edlund, H. (1999). Notch signalling controls pancreatic cell differentiation. Nature 400, 877-881.

Axelson, H. (2004). The Notch signaling cascade in neuroblastoma: role of the basic helix-loop-helix proteins HASH-1 and HES-1. Cancer Lett. 204, 171-178.

Ball, D. W. (2004). Achaete-scute homolog-1 and Notch in lung neuroendocrine development and cancer. Cancer Lett. 204, 159-169.

Bertrand, N., Castro, D. S., and Guillemot, F. (2002). Proneural genes and the specification of neural cell types. Nat. Rev. Neurosci. 3, 517-530.

Blumberg, P. M. (1991). Complexities of the protein kinase C pathway. Mol. Carcinog. 4, 339-344.

Bolognani, F., and Perrone-Bizzozero, N.I. (2008). RNA-protein interactions and control of mRNA stability in neurons. J. Neurosci. Res. 86, 481-489.

Bourdeaut, F., Janoueix-Lerosey, I., Lucchesi, C., Paris, R., Ribeiro, A., de Pontual, L., Amiel, J., Lyonnet, S., Pierron, G., Michon, J., Peuchmaur, M., and Delattre, O. (2009). Cholinergic switch associated with morphological differentiation in neuroblastoma. J. Pathol. 219, 463-472.

Brewer, G. (2000). Regulation of c-myc mRNA decay in vitro by a phorbol ester-inducible, ribosome-associated component in differentiating megakaryoblasts. J. Biol. Chem. 275, 33336-33345.

Brewer, G. J., and Cotman, C. W. (1989). Survival and growth of hippocampal neurons in defined medium at low density: advantages of a sandwich culture technique or low oxygen. Brain Res. 494, 65-74.

Brose, N., and Rosenmund, C. (2002). Move over protein kinase C, you've got company: alternative cellular effectors of diacylglycerol and phorbol esters. J. Cell Sci. 115, 4399-4411.

Casarosa, S., Fode, C., and Guillemot, F. (1999). Mash1 regulates neurogenesis in the ventral telencephalon. Development 126, 525-534.

Cau, E., Casarosa, S., and Guillemot, F. (2002). Mash1 and Ngn1 control distinct steps of determination and differentiation in the olfactory sensory neuron lineage. Development 129, 1871-1880.

Chen, H., Thiagalingam, A., Chopra, H., Borges, M. W., Feder, J. N., Nelkin, B. D., Baylin, S. B., and Ball, D. W. (1997). Conservation of the Drosophila latlung cancer: a hairy-related protein (HES-1) directly represses achaetescute homolog-1 expression. Proc. Natl. Acad. Sci. U.S.A. 94, 5355-5360.

de Pontual, L., Nepote, V., Attie-Bitach, T., Al Halabiah, H., Trang, H., Elghouzzi, V., Levacher, B., Benihoud, K., Auge, J., Faure, C., Laudier, B., Vekemans, M., Munnich, A., Perricaudet, M., Guillemot, F., Gaultier, C., Lyonnet, S., Simonneau, M., and Amiel, J. (2003). Noradrenergic neuronal development is impaired by mutation of the proneural HASH-1 gene in congenital central hypoventilation syndrome (Ondine's curse). Hum. Mol. Genet.12, 3173-3180.

Eichler, S. A., Kirischuk, S., Juttner, R., Schafermeier, P. K., Legendre, P., Lehmann, T. N., Gloveli, T., Grantyn, R., and Meier, J.C. (2008). Glycinergic tonic inhibition of hippocampal neurons with depolarizing GABAergic transmission elicits histopathological signs of temporal lobe epilepsy. J. Cell. Mol. Med. 12, 2848-2866.

Fähling, M., Mrowka, R., Steege, A., Kirschner, K. M., Benko, E., Forstera, B., Persson, P. B., Thiele, B. J., Meier, J. C., and Scholz, H. (2009). Translational regulation of the human achaete-scute homologue-1 by fragile X mental retardation protein. J. Biol. Chem. 284, 4255-4266. eral inhibition pathway in human

strong suppression relies on enhanced $h A S H 1$ mRNA degradation. Nevertheless, further studies on the molecular mechanisms regulating hASH1 synthesis in neuronal differentiation are necessary. In this regard, time dependent de-/activation of multiple pathways and trans-acting factors should be taken into account.

\section{ACKNOWLEDGMENTS}

We thank Regine Stöbe for excellent technical assistance. This work was supported by Deutsche Forschungsgemeinschaft (DFG) FA 845/2-1 to Michael Fähling, Sonderforschungsbereich SFB-TR3 B5 to Jochen C. Meier, and the Helmholtz Association (VH-NG-246 to Jochen C. Meier).

Fähling, M., Mrowka, R., Steege, A., Martinka, P., Persson, P. B., and Thiele, B. J. (2006a). Heterogeneous nuclear ribonucleoprotein-A2/B1 modulate collagen prolyl 4-hydroxylase, alpha (I) mRNA stability. J. Biol. Chem. 281, 9279-9286.

Fähling, M., Mrowka, R., Steege, A., Nebrich, G., Perlewitz, A., Persson, P. B., and Thiele, B. J. (2006b). Translational control of collagen prolyl 4-hydroxylase-alpha(I) gene expression under hypoxia. J. Biol. Chem. 281, 26089-26101.

Gestblom, C., Grynfeld, A., Ora, I., Ortoft, E., Larsson, C., Axelson, H., Sandstedt, B., Cserjesi, P., Olson, E. N., and Pahlman, S. (1999). The basic helix-loop-helix transcription factor dHAND, a marker gene for the developing human sympathetic nervous system, is expressed in both high- and low-stage neuroblastomas. Lab. Invest. 79, 67-79.

Gohlke, J. M., Armant, O., Parham, F. M., Smith, M. V., Zimmer, C., Castro, D. S., Nguyen, L., Parker, J. S., Gradwohl, G., Portier, C. J., and Guillemot, F. (2008). Characterization of the proneural gene regulatory network during mouse telencephalon development. BMC Biol. 6, 15. doi: 10.1186/1741-7007-6-15

Grynfeld, A., Pahlman, S., and Axelson, H. (2000). Induced neuroblastoma cell differentiation, associated with transient HES-1 activity and reduced HASH-1 expression, is inhibited by Notch1. Int. J. Cancer 88, 401-410.

Guhaniyogi, J., and Brewer, G. (2001). Regulation of mRNA stability in mammalian cells. Gene 265, 11-23.

Guillemot, F., Lo, L. C., Johnson, J. E., Auerbach, A., Anderson, D. J., and Joyner, A. L. (1993). Mammalian achaete-scute homolog 1 is required for the early development of olfactory and autonomic neurons. Cell 75, 463-476.

Hirsch, M. R., Tiveron, M. C., Guillemot, F., Brunet, J. F., and Goridis, C. (1998). Control of noradrenergic differentiation and Phox2a expression by MASH1 in the central and peripheral nervous system. Development 125 , 599-608.

Horton, S., Meredith, A., Richardson, J. A., and Johnson, J. E. (1999). Correct coordination of neuronal differentiation events in ventral forebrain requires the bHLH factor MASH1. Mol. Cell. Neurosci. 14, 355-369.

Howard, M. J. (2005). Mechanisms and perspectives on differentiation of autonomic neurons. Dev. Biol. 277, 271-286.

Ichimiya, S., Nimura, Y., Seki, N., Ozaki, T., Nagase, T., and Nakagawara, A. (2001) Downregulation of hASH1 is associated with the retinoic acid-induced differentiation of human neuroblastoma cell lines. Med. Pediatr. Oncol. 36, 132-134.

Insel, P. A., and Ostrom, R. S. (2003). Forskolin as a tool for examining adenylyl cyclase expression, regulation, and $\mathrm{G}$ protein signaling. Cell. Mol. Neurobiol. 23, 305-314.

Ito, T., Udaka, N., Ikeda, M., Yazawa, T., Kageyama, R., and Kitamura, H. (2001).Significance of proneural basic helix-loop-helix transcription factors in neuroendocrine differentiation of fetal lung epithelial cells and lung carcinoma cells. Histol. Histopathol. 16, 335-343.

Jessberger, S., Toni, N., Clemenson, G. D. Jr., Ray, J., and Gage, F. H. (2008). Directed differentiation of hippocampal stem/progenitor cells in the adult brain. Nat. Neurosci. 11, 888-893.

Jiang, T., Collins, B. J., Jin, N., Watkins, D. N., Brock, M. V., Matsui, W., Nelkin, B. D., and Ball, D. W. (2009). Achaetescute complex homologue 1 regulates tumor-initiating capacity in human small cell lung cancer. Cancer Res. 69, 845-854.

Jogi, A., Ora, I., Nilsson, H., Lindeheim, A., Makino, Y., Poellinger, L., Axelson, H., and Pahlman, S. (2002). Hypoxia alters gene expression in human neuroblastoma cells toward an immature and 
neural crest-like phenotype. Proc. Natl. Acad. Sci. U.S.A. 99, 7021-7026.

Johansson, T.A., Westin, G., and Skogseid, B. (2009). Identification of achaetescute complex-like 1 (ASCL1) target genes and evaluation of DKK1 and TPH1 expression in pancreatic endocrine tumours. BMC Cancer 9, 321. doi: 10.1186/1471-2407-9-321

Kageyama, R., Ohtsuka, T., Hatakeyama, J., and Ohsawa, R. (2005). Roles of bHLH genes in neural stem cell differentiation. Exp. Cell Res. 306, 343-348.

Kirschner, K. M., Wagner, N., Wagner, K. D., Wellmann, S., and Scholz, H. (2006). The Wilms tumor suppressor Wt1 promotes cell adhesion through transcriptional activation of the alpha4integrin gene. J. Biol. Chem. 281, 31930-31939.

Kuersten, S., and Goodwin, E. B. (2003). The power of the $3^{\prime}$ UTR: translational control and development. Nat. Rev. Genet. 4, 626-637.

Liu, W.S., and Heckman, C.A. (1998). The sevenfold way of PKC regulation. Cell. Signal. 10, 529-542.

Lo, L., Tiveron, M. C., and Anderson, D. J. (1998). MASH1 activates expression of the paired homeodomain transcription factor Phox2a, and couples pan-neuronal and subtypespecific components of autonomic neuronal identity. Development 125 , 609-620.

Martino, S., di Girolamo, I., Orlacchio, A., Datti, A., and Orlacchio, A. (2009). MicroRNA implications across neurodevelopment and neuropathology. J. Biomed. Biotechnol. 2009, 654346. doi: 10.1155/2009/654346.
McGovern, S., Pan, J., Oliver, G., Cutz, E., and Yeger, H. (2010). The role of hypoxia and neurogenic genes (Mash-1 and Prox-1) in the developmental programming and maturation of pulmonary neuroendocrine cells in fetal mouse lung. Lab. Invest. 90, 180-195.

Mellor, H., and Parker, P. J. (1998). The extended protein kinase C superfamily. Biochem. J. 332(Pt 2), 281-292.

Morioka, H., Ishihara, M., Shibai, H., and Suzuki, T. (1985). Staurosporineinduced differentiation in a human neuro-blastoma cell-line, $\mathrm{Nb}$-1. Agric. Biol. Chem. 49, 1959-1963.

Newton, A. C. (2001). Protein kinase C: structural and spatial regulation by phosphorylation, cofactors, and macromolecular interactions. Chem. Rev. 101, 2353-2364.

Osada,H.,Tomida,S.,Yatabe,Y.,Tatematsu, Y., Takeuchi, T., Murakami, H., Kondo, Y., Sekido, Y., and Takahashi, T. (2008). Roles of achaete-scute homologue 1 in DKK1 and E-cadherin repression and neuroendocrine differentiation in lung cancer. Cancer Res. 68, 1647-1655.

Ross, J. (1995). mRNA stability in mammalian cells. Microbiol. Rev. 59, 423-450.

Ross, S. E., Greenberg, M. E., and Stiles, C. D. (2003). Basic helix-loop-helix factors in cortical development. Neuron 39, 13-25.

Sasaki, A., Kanai, M., Kijima, K., Akaba, K., Hashimoto, M., Hasegawa, H., Otaki, S., Koizumi, T., Kusuda, S., Ogawa, Y., Tuchiya, K., Yamamoto, W., Nakamura, T., and Hayasaka, K. (2003). Molecular analysis of congenital central hypoventilation syndrome. Hum. Genet. 114, 22-26.
Soderholm, H., Ortoft, E., Johansson, I., Ljungberg, J., Larsson, C., Axelson, H., and Pahlman, S. (1999). Human achaete-scute homologue 1 (HASH-1) is downregulated in differentiating neuroblastoma cells. Biochem. Biophys. Res. Commun. 256, 557-563.

Sriuranpong, V., Borges, M. W., Strock, C. L., Nakakura, E. K., Watkins, D. N. Blaumueller, C. M., Nelkin, B. D., and Ball, D. W. (2002). Notch signaling induces rapid degradation of achaetescute homolog 1. Mol. Cell. Biol. 22 , 3129-3139.

Tamaoki, T., Nomoto, H., Takahashi, I., Kato, Y., Morimoto, M., and Tomita, F. (1986). Staurosporine, a potent inhibitor of phospholipid/Ca+t dependent protein kinase. Biochem. Biophys. Res. Commun. 135, 397-402.

Toullec,D.,Pianetti,P.,Coste,H., Bellevergue, P., Grand-Perret, T., Ajakane, M., Baudet, V., Boissin, P., Boursier, E., Loriolle, F. and. (1991). The bisindolylmaleimide GF 109203X is a potent and selective inhibitor of protein kinase C. J. Biol. Chem. 266, 15771-15781.

Vierbuchen, T., Ostermeier, A., Pang, Z.P., Kokubu, Y., Sudhof, T. C., and Wernig, M. (2010). Direct conversion of fibroblasts to functional neurons by defined factors. Nature 463, 1035-1041.

Wildner, H., Muller, T., Cho, S. H., Brohl, D., Cepko, C. L., Guillemot, F., and Birchmeier,C. (2006).dILA neurons in the dorsal spinal cord are the product of terminal and non-terminal asymmetric progenitor cell divisions, and require Mash1 for their development. Development 133, 2105-2113.

Yang, C., and Kazanietz, M. G. (2003). Divergence and complexities in DAG signaling: looking beyond PKC. Trends Pharmacol. Sci. 24, 602-608.

Yang, C., Kim, H. S., Seo, H., Kim, C. H., Brunet, J. F., and Kim, K. S. (1998) Paired-like homeodomain proteins, Phox $2 \mathrm{a}$ and Phox $2 \mathrm{~b}$, are responsible for noradrenergic cell-specific transcription of the dopamine betahydroxylase gene. J. Neurochem. 71, 1813-1826.

Zellmer, E., Zhang, Z., Greco, D., Rhodes, J., Cassel, S., and Lewis, E. J. (1995). A homeodomain protein selectively expressed in noradrenergic tissue regulates transcription of neurotransmitter biosynthetic genes. J. Neurosci. $15,8109-8120$.

Conflict of Interest Statement: The authors declare that the research was conducted in the absence of any commercial or financial relationships that could be construed as a potential conflict of interest.

Received: 25 August 2010; accepted: 20 January 2011; published online: 07 February 2011.

Citation: Benko E, Winkelmann A, Meier JC, Persson PB, Scholz H and Fähling $M$ (2011) Phorbol-ester mediated suppression of hASH1 synthesis: multiple ways to keep the level down. Front. Mol. Neurosci. 4:1. doi: 10.3389/fnmol.2011.00001

Copyright ( 2011 Benko, Winkelmann, Meier, Persson, Scholz and Fähling. This is an open-access article subject to an exclusive license agreement between the authors and Frontiers Media SA, which permits unrestricted use, distribution, and reproduction in any medium, provided the original authors and source are credited. 


\section{APPENDIX}

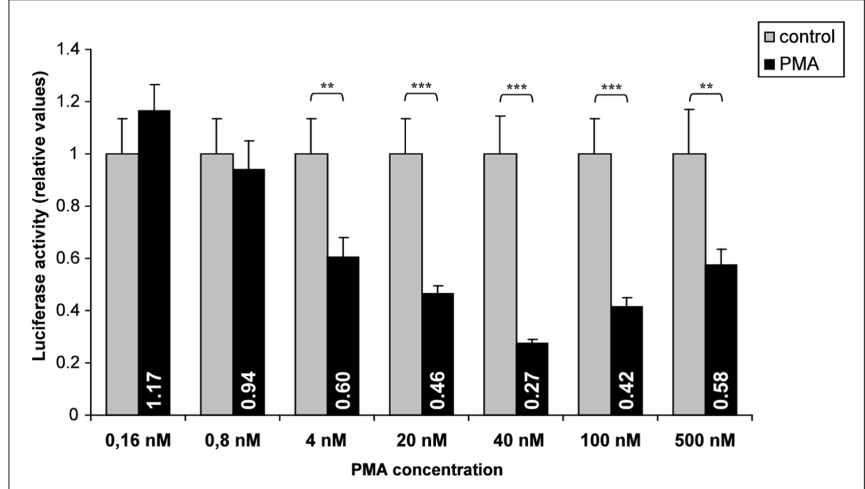

FIGURE A1 | Phorbol 12-myristate 13-acetate dose dependent suppression mediated by hASH1 mRNA UTRs. Kelly neuroblastoma cells were transiently transfected with reporter gene constructs in which the luciferase mRNA UTRs were replaced by the hASH1 5'- and $3^{\prime}$ UTRs.

Luciferase activity was measured following $24 \mathrm{~h}$ PMA administration. $n=12$; ${ }^{* *} p<0.01,{ }^{*} p<0.001$.

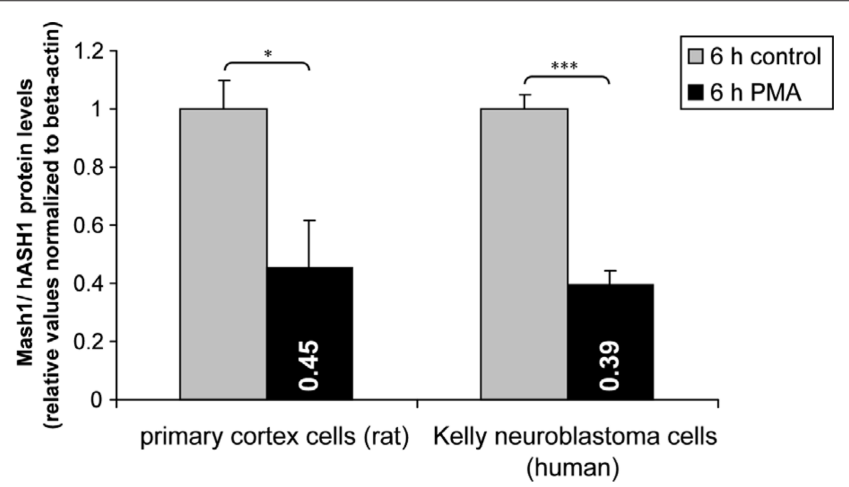

FIGURE A3 | Phorbol 12-myristate 13-acetate mediated suppression of Mash1/hASH1 protein levels. Isolated primary cortex cells of the rat and human neuroblastoma-derived Kelly cells were treated for $6 \mathrm{~h}$ with PMA $(40 \mathrm{nM})$. Relative Mash $1 / \mathrm{hASH} 1$ protein levels were quantified by Western blot analysis. $n=3 ;{ }^{*} p<0.05,{ }^{* * *} p<0.001$.

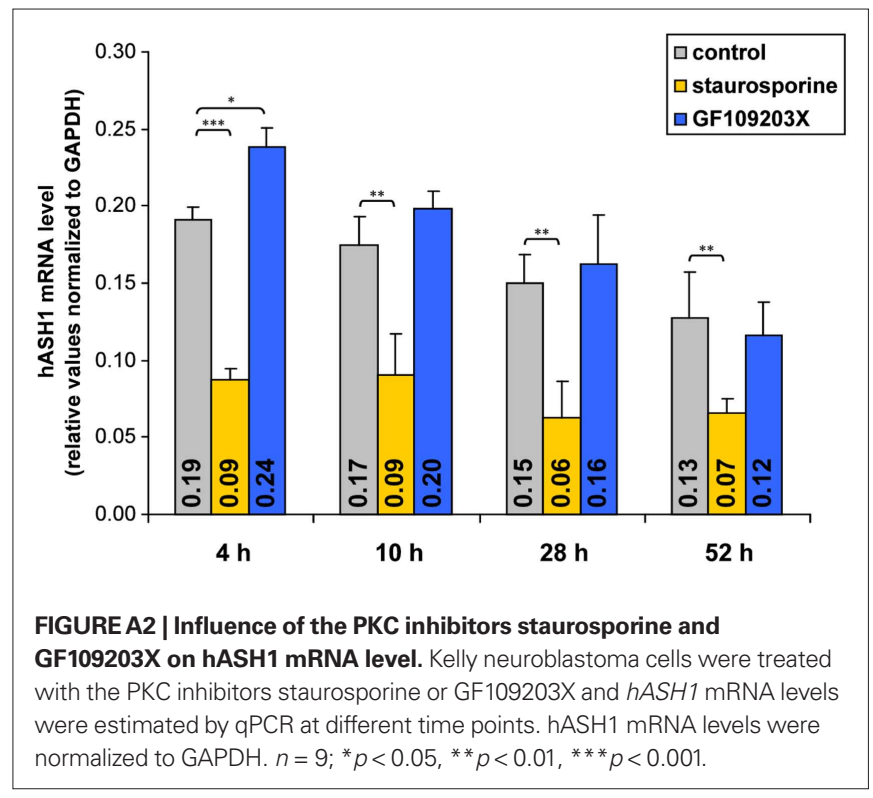

